\title{
アルミニウム合金用高速ロールキャスター
}

羽賀 俊雄

\begin{abstract}
Journal of The Japan Institute of Light Metals, Vol. 70, No. 6 (2020), 234-243
\end{abstract}
(C) 2020 The Japan Institute of Light Metals

\section{High speed roll casters for aluminum alloys}

\author{
Toshio HAGA
}

Keywords: single roll caster; twin roll caster; clad strip caster; high speed roll caster

\section{1. 緒言}

双ロールキャスターは，アルミニウム合金やマグネシウム 合金に使用する軽金属用のものと鉄鋼用のものに大別されて きた。両プロセスを比較すると軽金属用は低速・高荷重で横 型が多く，鉄鋼用は高速・低荷重で縦型が多い。双ロール キャスターは横型と縦型で分類することもあるが，低速・高 荷重または，高速・低荷重で分類する方が適当と考えられ る。ここでは, アルミニウム合金の板鋳造に使用することを 目的に考案した高速・低荷重の双ロールキャスター, 自由凝 固面の平坦化を試みた単ロールキャスター，およびこれらか ら発展したクラッド板用双ロールキャスターなどについて示 す。

\section{2. 高速双ロールキャスター}

\section{1 縦型双ロールキャスター}

一般的なアルミニウム合金用の双ロールキャスターは，凝 固と熱間圧延を同時に行う。熱間圧延には強固な鋼ロールが 必要である。したがって，シェルを厚くする必要があり，冷 却水路からロール表面までの距離は長くなるのでロールの冷 却能を高くすることは困難である。鋼ロールを使用して熱間 圧延を行うため，板がロールへ固着するが，これを防ぐため に離型剂をロールへ噴霧する。離型剂はロールと溶湯の接触 状態を均一にする効果もあるが，一方，熱抵抗にもなる。つ まり離型剂は，鋳造速度を低下させる。従来の双ロールキャ スターの改善では, 鋳造速度の高速化は困難と考えた。そこ で単ロール法の一種であるメルトドラッグ法 ${ }^{1}{ }^{1}$, およびメル トドラッグ法にロールを付加したメルトドラッグ双ロール 法 $^{2)}$ から高速双ロールキャスターに関する研究を開始した。 銅合金ロールを使用すると離型剂を使用しなくても板がロー ルに固着しないことがメルトドラッグ法に関する研究より判
明した。また，ロールと溶湯が接する位置の溶湯ヘッド圧を 高めるとリップルマークを改善できることが明らかになっ た $^{1)}$ 。鋳造と同時に熱間圧延を行わなければ，冷却能が高い 銅合金ロールを使用できるので鋳造速度の高速化が可能にな ると考えた。考案した高速双ロールキャスターを図1に示す。 図 1 (a)，（b）に縦型高速双ロールキャスターの模式図とロー ルの周辺をそれぞれ示す。鋳造板の搬送のためには横型が良 いが, 注湯が容易と判断して縦型を採用した。縦型高速双 ロールキャスターは, 鉄鋼用の縦型双ロールキャスター ${ }^{3)}$ と 似ているが, フロントダムプレートを装着している点が異な る。フロントダムプレートは，ロールと溶湯が接する位置の 溶湯ヘッド圧を高めるために採用した。また，フロントダム プレートは，溶湯面の位置（溶湯へッド）が変動しても凝固 距離（材料とロールが接触する距離）を一定にすること, つ まり板厚を一定にすることにも効果がある。本研究の縦型双 ロールキャスターと鉄鋼用の双ロールキャスターでは，フロ ントダムプレート以外にロール荷重が異なる。鉄鋼用の双 ロールキャスターのロール荷重は $0.01 \sim 0.1 \mathrm{kN} / \mathrm{mm}$ に対して 本提案の縦型高速双ロールキャスターでは $0.1 \sim 1 \mathrm{kN} / \mathrm{mm}$ と大 きい。しかし，一般的な軽合金用の双ロールキャスターの ロール荷重 $1 \sim 20 \mathrm{kN} / \mathrm{mm}$ と比較すると小さい。鋼と比較して 熱伝導率が高い銅合金のロールを使用することで, 例えば $\mathrm{AC} 4 \mathrm{C}$ では $120 \mathrm{~m} / \mathrm{min}$ の高速で板を鋳造できた。銅合金ロール の効果で板の冷却速度も高く, 熊井らは板の表面近傍の冷却 速度は $4000^{\circ} \mathrm{C} / \mathrm{s}$ に達すると報告している ${ }^{4)}$ 。縦型高速双ロー ルキャスターでは, 表 1 に示す寸法のロールを使用して実験 を行った。ロール径が大きいほど厚い板の鋳造が容易であっ た。ロール幅は, 板の鋳造の容易さには影響を及ぼさなかっ た。

従来の横型の双ロールキャスターでは, 注湯前からロール 間隙は鋳造板の厚さに設定し, 注湯を開始する。初期のハン

大阪工業大学（†535-8585 大阪市旭区大宮 5-16-1） Osaka Institute of Technology（5-16-1 Omiya, Asahi-ku, Osaka-shi, Osaka 535-8585） E-mail : toshio.haga@oit.ac.jp 受付日：2020年3月 13 日 受理日：2020年4月 20 日 


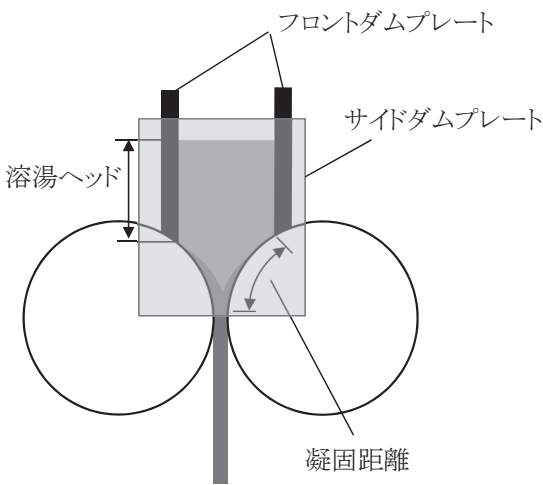

（a）縦型高速双ロールキャスター

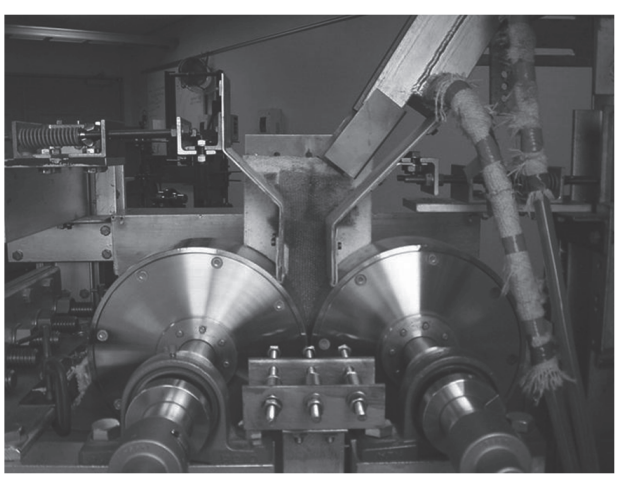

（b）縦型高速双ロールキャスターのロール周辺

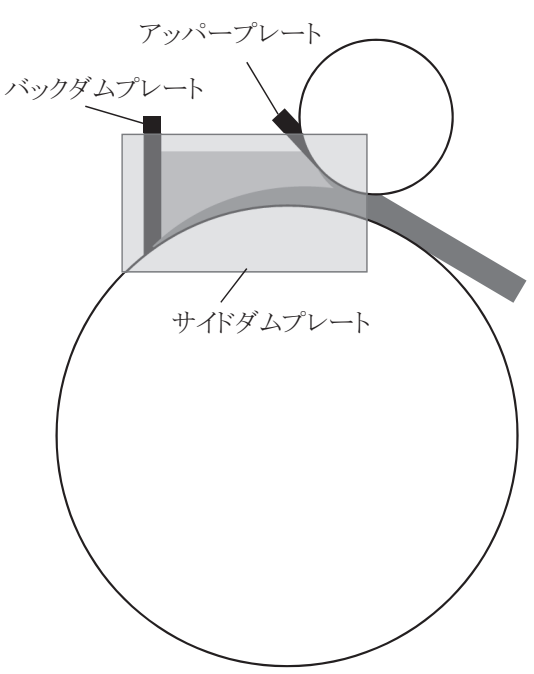

（c）異径双ロールキャスター

図1 縦型高速双ロールキャスターと異径双ロールキャスター

表 1 縦型高速双ロールキャスターで使用したロールの寸法

\begin{tabular}{c|c}
\hline \hline ロール直径, $R \mathrm{~d}(\mathrm{~mm})$ & ロール幅, $R \mathrm{w}(\mathrm{mm})$ \\
\hline 300 & $50,100,200,600$ \\
600 & $100, \quad 200,600$ \\
1000 & 100,200
\end{tabular}

ター法の様に下方から注湯する場合は溶湯がロール間隙から 漏れることは無いと考えられるが，横型ではロール間隙から 溶湯が漏れだす場合がある。注湯初期にはロール周速を低速 にすることやストッパを使用することで対処している。縦型 高速双ロールキャスターでは, 圧延機のようにロールの位置 を固定せず, 注湯開始時はロール間隙を $0.5 \sim 1 \mathrm{~mm}$ と狭くし, 鋳造板がロール間隙を押し開く機構とした。このため注湯初 期にロール間隙から溶湯が漏れることは無い。実験室サイズ のキャスターでは，ばねを使用して簡易的に溶湯の漏れ対策 とロールの荷重制御と位置制御を行っているが, 生産機に近 いものは油圧によりこれらを行っている。図2に秋葉ダイカ ス卜工業所の生産機に近い縦型高速ロールキャスターを示
す。ロールの位置が荷重により移動することは，ロール間隙 で試料が詰まりロールが停止することを防ぐことにも効果が ある。

バネを使用した簡易的な溶湯の漏れ対策とロールの荷重制 御と位置制御は, 後述の双ロールキャスターでも採用した。

\section{2 異径双ロールキャスター}

高ロール周速の特長を有し, さらに鋳造板の搬送の利便 性, 厚い板を鋳造する時の凝固距離の延長の容易さ, サイド ダムプレートの面積低減, 容易な注湯方法を考慮して考案し たのが図 1 (c) に示す異径双ロールキャスターである ${ }^{5), 6) 。 下 ~}$ のロールの径は上のロールの径より大きく, 下のロールの凝 固距離は上ロールの凝固距離より長い。したがって, 上下の ロールで凝固した層の厚さは異なる。凝固距離を設定するた めに上ロールにはアッパープレート, 下ロールにはバックダ ムプレートを取り付けた。上ロールの位置は下ロールの直上 より $15^{\circ}$ 傾いている。これは, 注湯開始時と注湯終了時の溶湯 量が不十分なときに上ロールと溶湯が接触しやすくし，下 ロールの凝固層で上ロールが損傷しないようにしたためであ る。メルトドラッグ法では, 合金によってはノズル内で溶湯

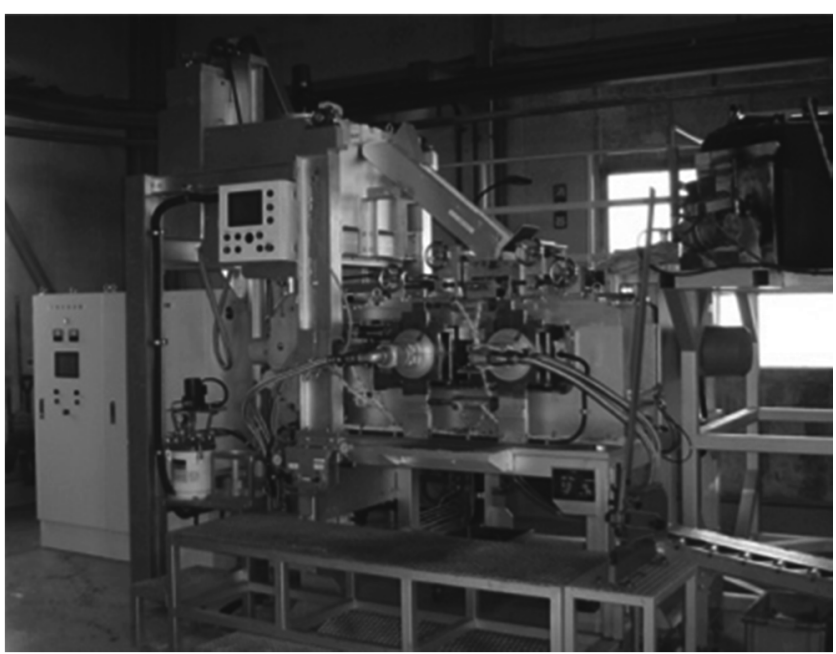

(a) 全景

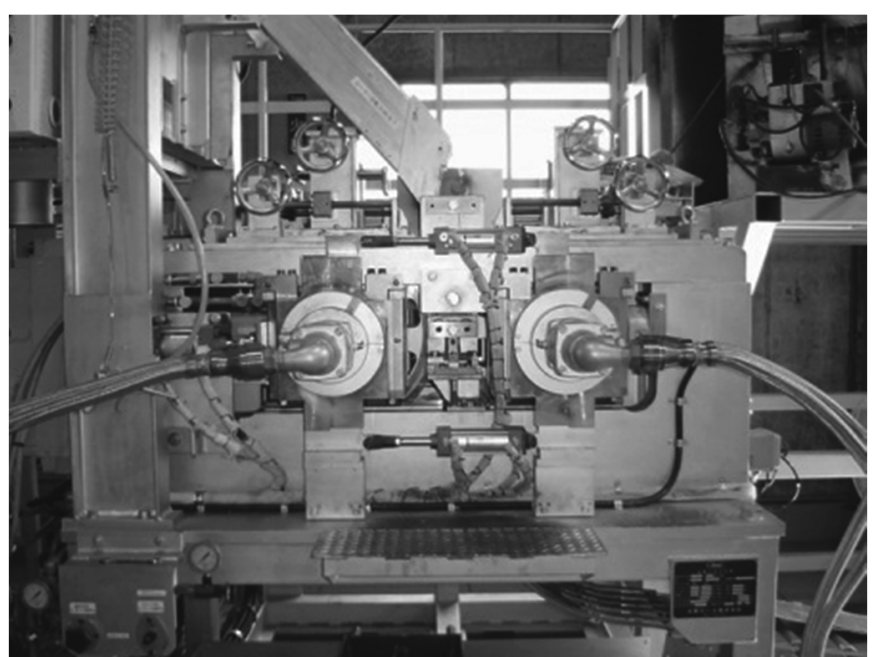

（b）ロール周辺

図2 生産機に近い装備の実験用縦型高速双ロールキャスター（株式会社秋葉ダイカスト工業所） 
が凝固する場合があったので，これに対処するため異径双 ロールキャスターではロール面上に注湯した。異径双ロール キャスターは, 縦型高速双ロールキャスターと比較すると 60 $\mathrm{m} / \mathrm{min}$ より高速での鋳造には適していないが, 厚い板の鋳造 が可能であり，鋳造板の搬送が容易である。AC4CやAC7Aで あれば厚さが $8 \mathrm{~mm}$ 程度の板の鋳造が可能である。板の厚さ が同じであれば，縦型高速双ロールキャスターと異径双ロー ルキャスターで鋳造した板の特性に顕著な差異は無かった。 異径双ロールキャスターで実験を行ったロール径の寸法を表 2 に示す。縦型高速双ロールキャスターと異径双ロールキャ スターの鋳造の様子を図3に示す。

\section{3 ロール}

6022 のように Si 量が1\%程度の合金においてロール荷重が $0.1 \sim 0.2 \mathrm{kN} / \mathrm{mm}$ と小さい場合は，図4(a)に示すように鋳造板 の表面に割れが発生する場合があった。割れの発生は溶湯と ロールの接触不良個所における凝固遅れが原因であると考え られる。ロール面に溝を加工すると図 4(b)，（c）のように鋳 造板の表面の割れを改善することができた ${ }^{7)}$ 。図5にロール

表 2 異径双ロールキャスターで使用したロールの寸法

\begin{tabular}{c|c|c}
\hline \hline $\begin{array}{c}\text { 上ロール直径, } \\
\operatorname{Rud}(\mathrm{mm})\end{array}$ & $\begin{array}{c}\text { 下ロール径, } \\
R \mathrm{ld}(\mathrm{mm})\end{array}$ & $\begin{array}{c}\text { ロール幅, } \\
R \mathrm{w}(\mathrm{mm})\end{array}$ \\
\hline 250 & 1000 & 100 \\
300 & 1000 & 100,400 \\
500 & 800 & 400 \\
500 & 1200 & 500 \\
\hline
\end{tabular}

の溝の形状を示す。ロール面の溝は，微視的に見ると溶湯と ロール面の接触状態を不均一にするが，巨視的見ると溶湯と ロールの接触状態が均一になり, 凝固遅れが原因の割れの発 生を防ぐことに有効であった。鋳造板の突起の形状から溶湯 は溝に充満していないと考えられる。溝付きのロールを使用 すると溶湯とロールの接触面積は小さくなるので冷却速度は 低下する。したがって鋳造板の表面の組織は平坦なロールで 鋳造した板より大きくなった。しかし，内部の組織には差異 は無かった。冷却速度の低下により鋳造板の表面の柱状晶の チル層が無くなり，チル層の粒界で発生する割れも改善され た。

フロントダムプレートとロールの間隙を $3 \mathrm{~mm}$ 程度とし， フロントダムプレートとロールの間に湯だまりを保持する方 法も表面の割れの改善に効果があった。溶湯とロールは湯だ
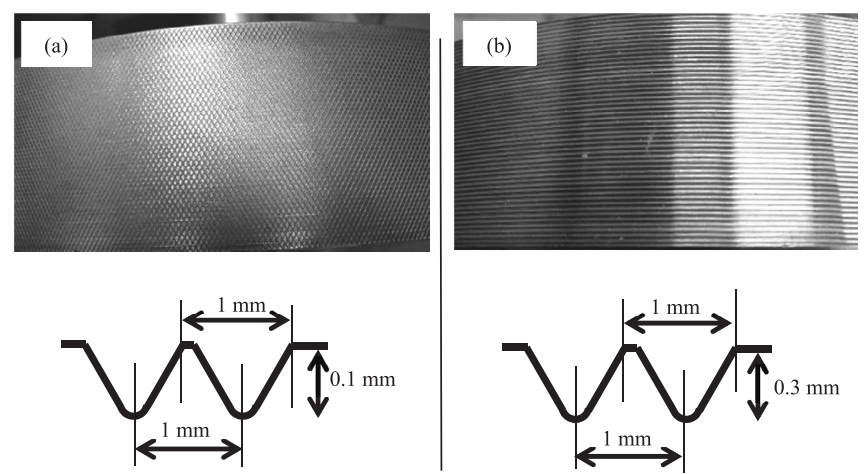

図 5 溝付きロールの表面状態と溝の寸法（a）クロス 溝, (b) 平行溝

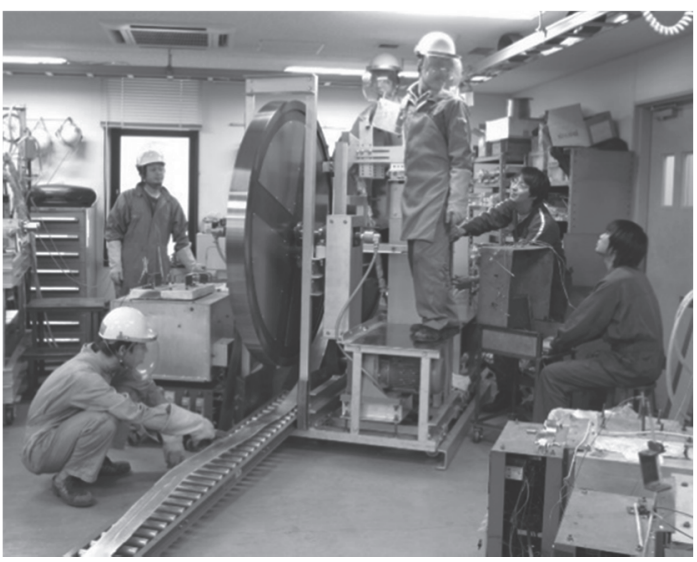

(a) 縦型高速双ロールキャスター

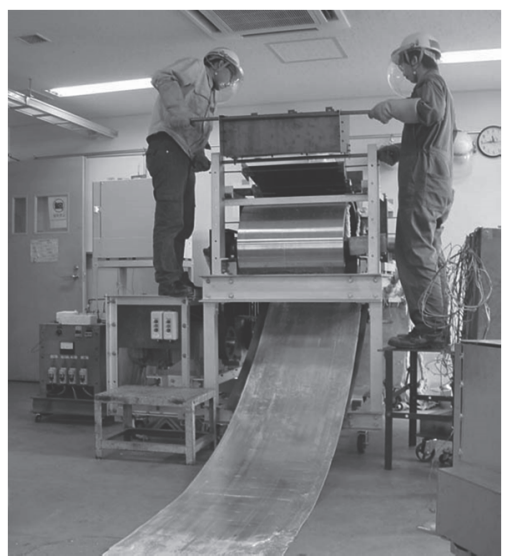

（b）縦型高速双ロールキャスター

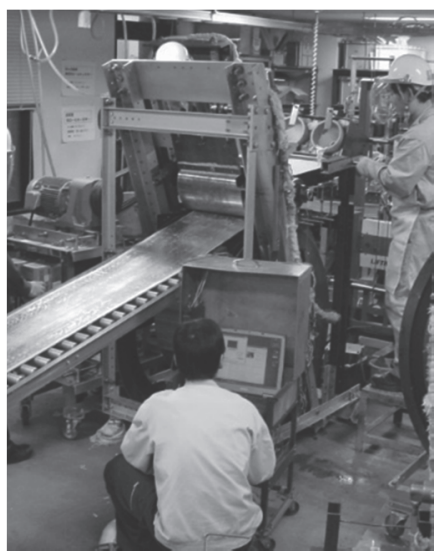

(c) 異径双ロールキャスター

図3 双ロールキャスターによる板の鋳造の様子（a）ロール直径 $1000 \mathrm{~mm}$ ，ロール幅 $100 \mathrm{~mm}$, （b） ロール直径 $600 \mathrm{~mm}$, ロール幅 $600 \mathrm{~mm}$, （c）上ロール：直径 $300 \mathrm{~mm}$, 幅 $400 \mathrm{~mm}$, 下ロール：直径 $1000 \mathrm{~mm}$, 幅 $400 \mathrm{~mm}$

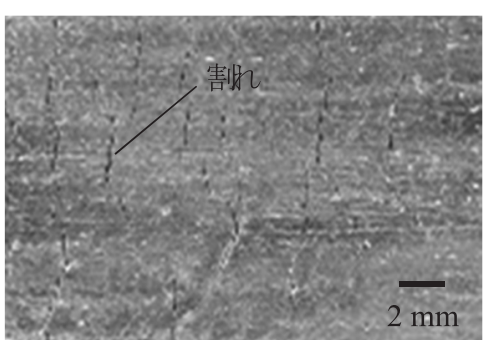

(a)

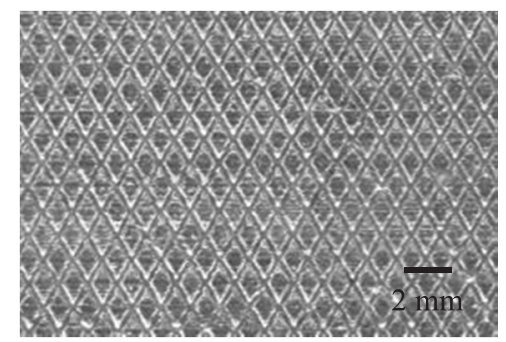

(b)

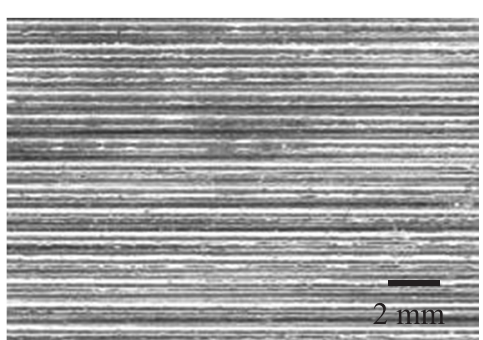

(c)

図4 ロール表面が異なるロールで鋳造した板の表面状態（a）フラットロール (通常のロール) 使用, (b) 図 5(a) のロール使用, (c) 図 5(b) のロール使用 
まりの中で接触を開始する。そのためへッド圧は無いのでチ ル層が発生するほど溶湯とロールの接触状態は良好ではな い。フロントダムプレートの直下では，フロントダムプレー トとロールの間隙が狭いので圧力が高くなり幅方向の接触状 態が均一かつ良好になると考えられる。フロントダムプレー 卜を使用しない場合と比較すると，鋳造板の表面状態は良好 であった。各プロセスと鋳造板の表面状態を図6に示す。図 6(c) がフロントダムプレートの外側に湯だまりを保持する 方法である。

縦型高速双ロールキャスターにおいてロール周速 $60 \mathrm{~m} /$ $\min$, ロール荷重 $0.17 \mathrm{kN} / \mathrm{mm}$ とし, 平坦なロールを使用, 溝 付きのロールを使用，および湯だまりを保持する方法で板を 鋳造した。鋳造板を曲げて表面の割れを比較したものを図7 に示す。溝付きのロールを使用，および湯だまりを保持する 方法で鋳造した板を曲げた場合は外表面に割れは発生しな かった。

$\mathrm{Al}-\mathrm{Mg}$ 合金やマグネシウム合金は鋼のロールに固着しな い。したがって溶湯とロール間の熱抵抗となる離型剂を使用 する必要が無い。しかし，銅合金のロールと比較すると冷却 能が低いためロール周速は銅合金のロールほど速くすること はできない。また，銅合金のロールと比較すると鋼のロール のロールコーティングは著しい。ここでロールコーティング は，従来の双ロールキャスターや圧延と同様にロールの表面 にアルミニウムが薄く固着したものを指す。しかし，鋼ロー ルは銅合金ロールと比較すると安価である。従来のアルミニ ウム合金用の双ロールキャスターの鋼ロールは，シェルをコ
アに焼きばめる方式で, シェルの厚さは25～60 mmである。 直径が600〜 $1000 \mathrm{~mm}$ のロールが周速 $1 \mathrm{~m} / \mathrm{min}$ 程度で回転する のであれば，鋳造板の板厚分布に対するロールの熱変形は無 視できるようである。しかし, 例えば $30 \mathrm{~m} / \mathrm{min}$ のような高速 で鋼ロールを使用すると, 冷却が間に合わずロールが樽型に 変形することが知られている。従来はシェルの幅方向の中央 部が特に円周方向に熱澎張するために樽型に変形すると考え られていた。しかし，幅が狭いロールを幅方向に連結した ロールや幅方向の中央部だけを冷却するロールを使用して実 験を行った結果, シェルの胴長方向の熱ひずみをロールの両 端で拘束するためにシェルが樽型に変形するとの結論に至っ た。シェルの中に胴長方向の冷却水路を設けコアとの接合方 法を工夫することで樽型に変形することを低減することがで きた。縦型高速双ロールキャスターでは，熱間圧延は行わな いので, 冷却水路の直径 $8 \mathrm{~mm}$, 水路間のリブの厚さ $10 \mathrm{~mm}$, 表面と水路の間隔は $4 \mathrm{~mm}$ と狭い鋼ロールを試作し, 実験を 行った ${ }^{8)}$ 。図8に示すように板厚分布が改善した。

\section{4 ばり}

双ロールキャスターにおいてサイドダムプレートを使用す ると鋳造板の両端に板に垂直方向にばりが発生する（以後縦 ばりと示す)。縦ばりは, サイドダムプレートを破壊する場合 もあるほか，コイルに巻く場合や冷間圧延では害をなす。鉄 鋼用の縦型双ロールキャスターもサイドダムプレートを使用 するが本研究の縦型高速双ロールキャスターの方がロール荷 重は大きいので縦ばりは著しいと考えられる。アルミニウム 合金と縦ばりの寸法の関係を図9に示す。Si量が多く半凝固
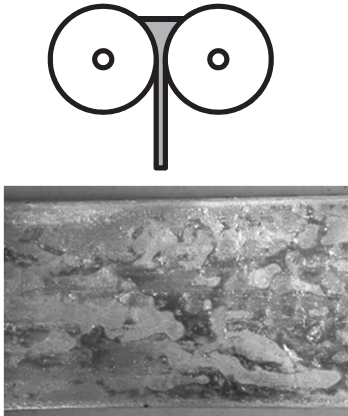

(a)
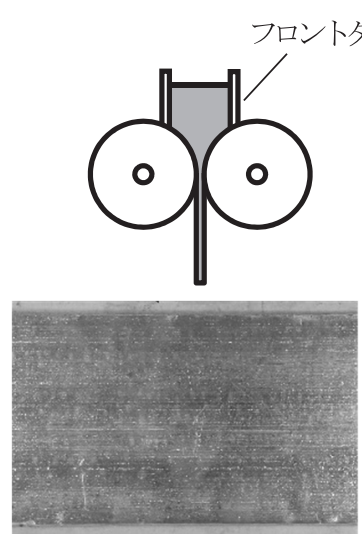

(b)
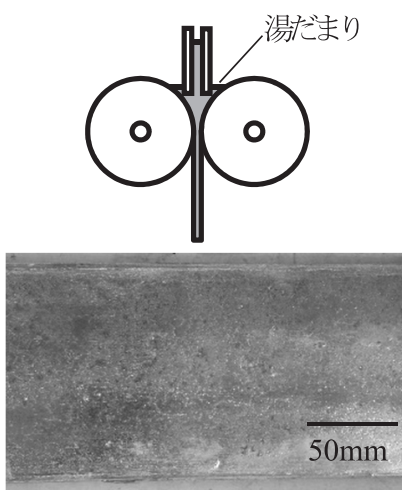

(c)

図6 鋳造板の表面状態に対するフロントダムプレートの有無，および湯だまりの影響

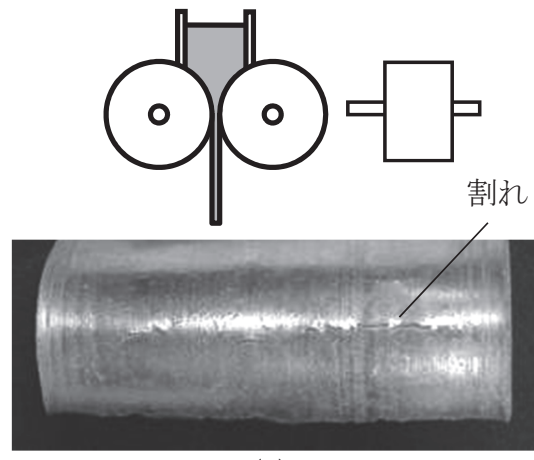

(a)

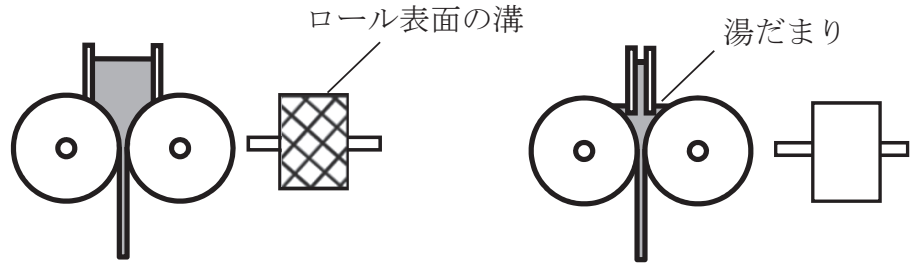

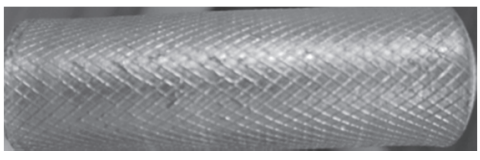

(b)

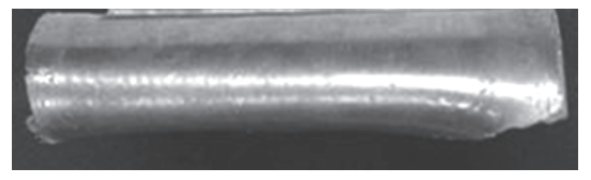

(c)

図7＼cjkstart折り曲げた鋳造板の外表面の割れに対するロール溝と湯だまりの影響 


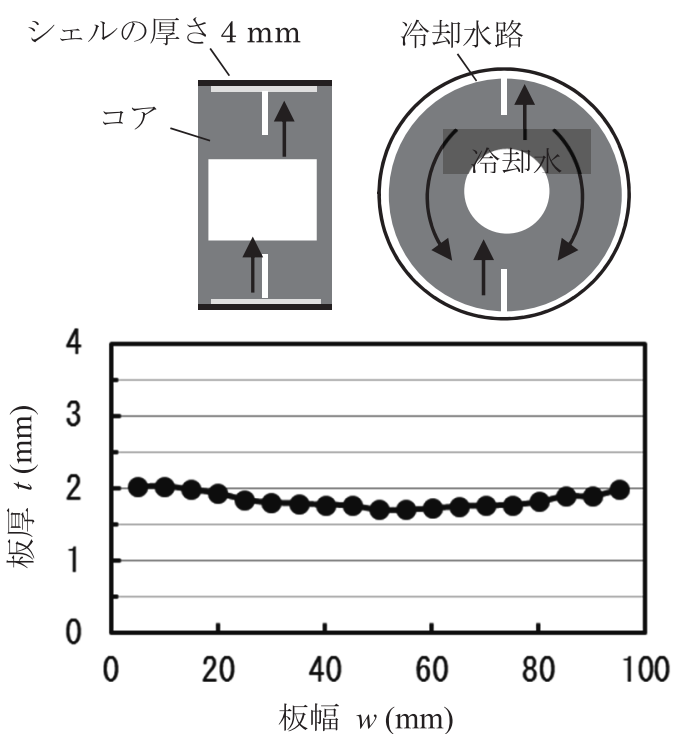

(a)

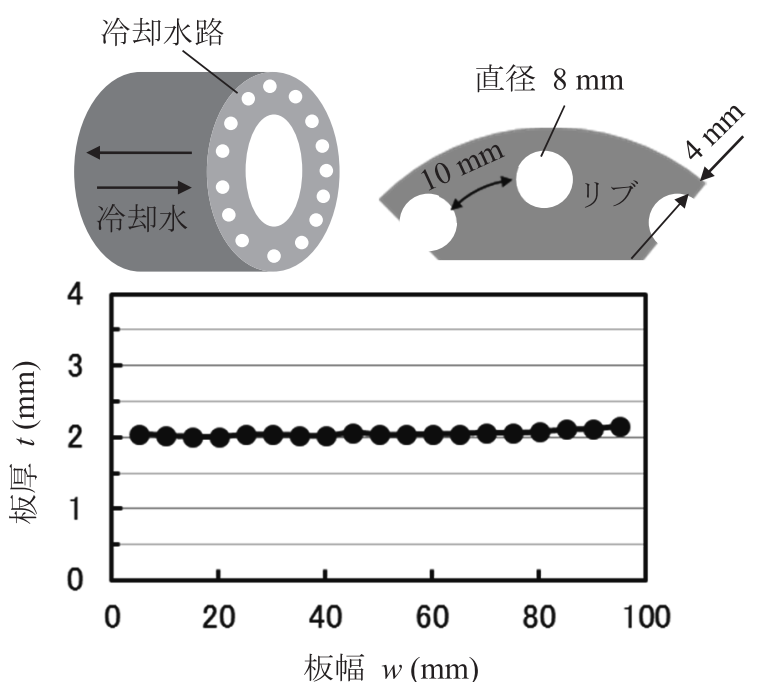

(b)

図8ロールの板厚分布に対するロールの構造の影響（鋼ロール）

（a）コアーシェルタイプ，（b）シェルに軸方向の冷却水路があるタイプ

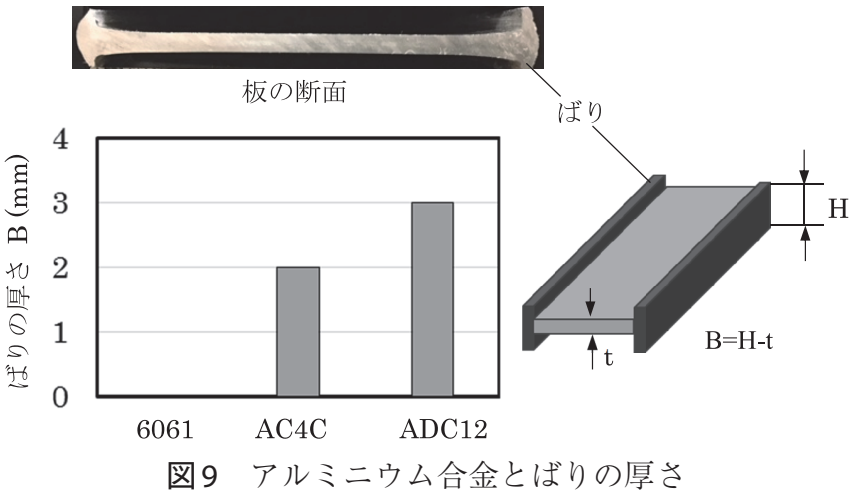

状態の流動性が高いほどばりは著しい。縦ばりは，ロール間 隙近傍で半凝固状態の部分が左右に押し出されて形成される と考えられる。サイドダムプレートの溶湯と接する面に貼り 付けた断熱シートのすり減り状態, サイドダムの下端の位置 およびサイドダムプレートに加工した穴からの半凝固状態の アルミニウム合金の噴出状態からばりの発生位置を調査し た。半凝固状態のアルミニウム合金がロール軸方向に押し出 される量はロール間隙が狭くなるほど多くなるわけではな く, 図10に示すばりが発生を開始する位置で最も多く, ロー ル間隙が狭くなるに従い少なくなった ${ }^{9)} 。 こ の$ 結果を基に縦 ばりを横ばり（ロール軸方向のばり）に変える方法を調查し た。サイドダムに図11に示すようなロールの円弧に沿って加 工した厚さ $10 \mathrm{~mm}$ の板（以後ばりチェンジャーと呼ぶ）を取 り付けることで縦ばりを横ばりに変えることができた ${ }^{10)}$ 。ば りチェンジャーの下端がばりの発生開始位置よりロール間隙 に近いと図 11 に示すように縦ばりを横ばりに変えることに 有効であった。

\section{3. 鋳造用合金への適用}

縦型高速ロールキャスターで鋳造した $\mathrm{AC} 3 \mathrm{~A}$ 板は冷間圧延 が可能であった。1 mmまで冷間圧延後に焼きなましを行い, 深絞り試験を行った。AC3Aの Si 量は $11.24 \%, F e$ 量は $0.44 \%$

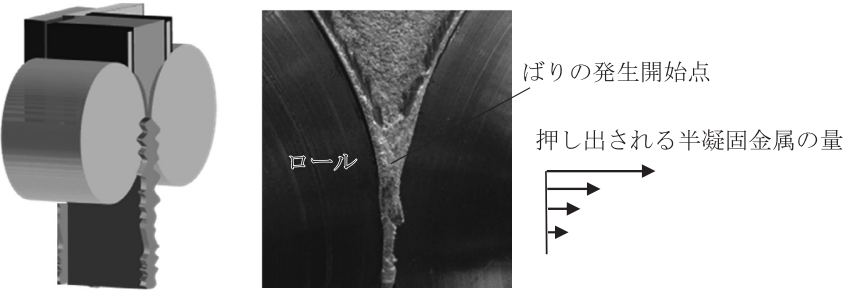

図 10 鋳造途中でロールを停止して材料を凝固させた ロール間隙周辺の様子

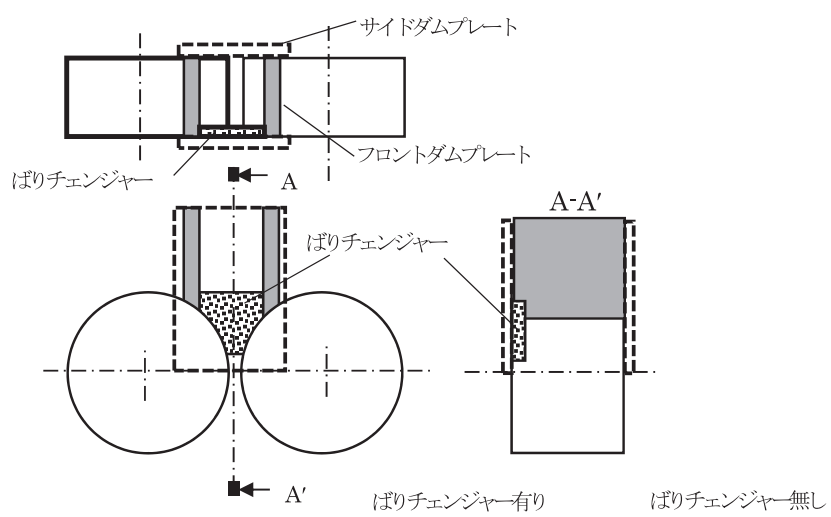

縦ばり
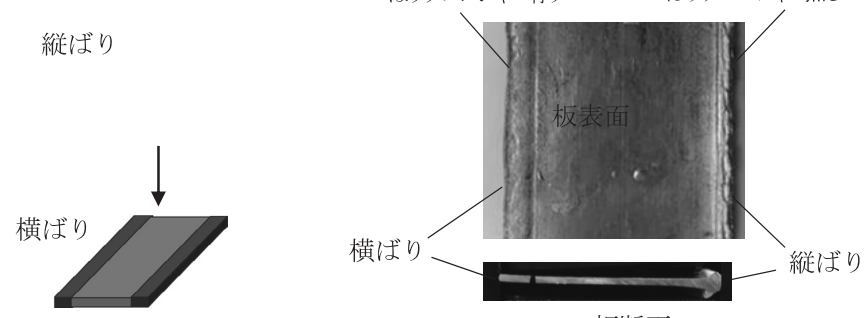

板断面

図11 ばりチェンジャーの模式図とばりチェンジャー により成形した横ばり

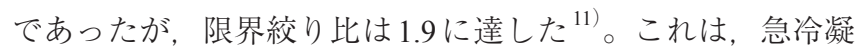
固により共晶 $\mathrm{Si}$ や $\mathrm{AlFeSi}$ 系の金属間化合物が微細粒状化した ためであると推測できる。 Magsimal-59を模してAC7Aに2\% 
の $\mathrm{Si}$ 添加したものをロールキャストした。1 mm まで泠間圧 延可能であり，焼きなましの後に深絞りを行った。限界絞り 比は2.0であった。AC3A と AC7Aに2\%の Si を添加したもの を深絞りした結果を図12に示す。これらは高速双ロールキャ スターで急冷凝固することにより鋳造用アルミニウム合金を 塑性加工である板成形に使用できる，つまり鋳造用合金で鋳 造と塑性加工の合金を統一できる可能性を示す結果であると 考えられる。高速双ロールキャスターで鋳造したAC7A板や 5182 板を深絞りすると縞や割れが発生する場合があった（図 19(a))。しかし，Siを $2 \%$ 添加すると縞や割れが発生しなかっ た。 $\mathrm{AC} 3 \mathrm{~A} の \mathrm{Fe}$ 量が $0.44 \%$ であり板成形用のアルミニウム合 金である 6022 と比較すると $\mathrm{Fe}$ 量は $0.3 \%$ 程度多い。AC3Aに さらに $0.2 \%$ の $\mathrm{Fe}$ を添加しても限界絞り比は $1.9 あ り ， 0.6 \%$ の $\mathrm{Fe}$ を添加しても限界絞り比は1.7であった。この結果はリサ イクル時の不純物としての $\mathrm{Fe}$ の増加に対して板成形性の低 下が少ないことを示していると考えられる。これらを総合す ると，高速ロールキャストした鋳造用アルミニウム合金は， 鋳造と塑性加工に使用できるユニアロイの性質, さらに不純 物の無害化の可能性を示すと考えられる。

異径双ロールキャスターで鋳造した $\mathrm{AC} 4 \mathrm{CH}$ 合金板を冷間 圧延した時の圧下率に対する鋳造方向と幅方向の引張試験の 結果を図13に示す ${ }^{11)}$ 。異なる厚さの鋳造板を冷間圧延し，試 験片の厚さを $1 \mathrm{~mm}$ とした。圧下率が $80 \%$ 以上になると鋳造 方向と幅方向の差異, 特に伸びの差異は小さくなった。また, $\mathrm{AC} 4 \mathrm{C}$ 鋳造板を $1 \mathrm{~mm}$ まで冷間圧延し，焼きなまし材と $\mathrm{T} 4$ 材 に曲げ試験を行った結果を図 14 に示す。鋳造板の厚さが 3.0 $\mathrm{mm}$ の場合は両条件において外面に割れが発生したが，鋳造 板の厚さが $7.6 \mathrm{~mm}$ の場合は両条件において割れは発生しな かった。これらの結果は，鋳造板に対する鍛錬効果の必要性 を示していると考えられる。

\section{4. 難加工材}

アルミニウム合金の中に $\mathrm{SiC} の$ 粉末を添加した複合材料は 硬く，板を作製するためには熱間圧延を繰り返す必要があ り, 多くの工程を必要とする。双ロールキャスターでは薄板 を一工程で鋳造できるので, 熱間圧延の回数を削減すること ができる。縦型高速双ロールキャスターを使用して $\mathrm{Al}-\mathrm{SiC}_{\mathrm{p}}$ 複合材のロールキャスティングを試みた ${ }^{12)}$ 。図15(a) に示す ように $\mathrm{Al}-20 \mathrm{vol} \% \mathrm{SiC}_{\mathrm{p}}$ の鋳造板はコイルに巻くことができた。 これはマトリックスである $\mathrm{Al}-\mathrm{Si}$ 合金の共晶 $\mathrm{Si}$ が微細粒状化 したために，延性が改善されたためと考えられる。図 15(b) には， $\mathrm{Al}-30 \mathrm{vol} \% \mathrm{SiC}_{\mathrm{p}}$ 鋳造板の断面を示す。 $\mathrm{SiC}$ 粒子が凝集せ ずに分散している様子がわかる。 $\mathrm{Al}-\mathrm{SiC}_{\mathrm{p}}$ 複合材や $\mathrm{Mg}$ 合金な どの薄板の作製の場合のように熱間圧延を繰り返すことが必 要な材料には, 高速ロールキャスターは有効である。渡利ら は横型の高速双ロールキャスターで Mg-12\%Al-1\%Mn 合金板 の鋳造と熱間圧延に成功している ${ }^{13)}$ 。

\section{5. スクレイパーを装着した単ロールキャスター}

5182 のような $\mathrm{Mg}$ が3\%以上含まれている $\mathrm{Al}-\mathrm{Mg}$ 合金では従 来の双ロールキャスターにより鋳造した板には中心線偏析が 発生することが知られている。縦型高速双ロールキャスター や異径双ロールキャスターで鋳造した板にも中心線偏析が発 生する。単ロールキャスターの一種であるメルトドラッグ法

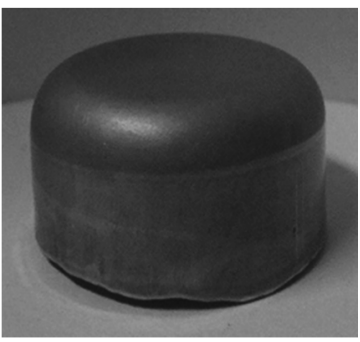

(a) $\mathrm{AC} 3 \mathrm{~A}$

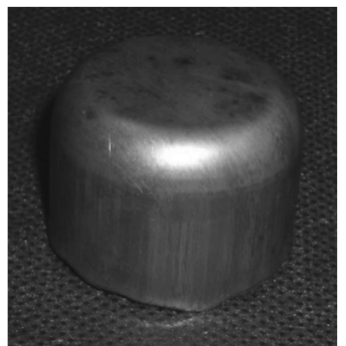

(b) $\mathrm{AC} 7 \mathrm{~A}+2 \% \mathrm{Si}$

図12 深絞り試験の結果（a）板厚：1.0 mm, LDR 1.9 , (b) 板厚 : $0.7 \mathrm{~mm}, \quad$ LDR : 2.0
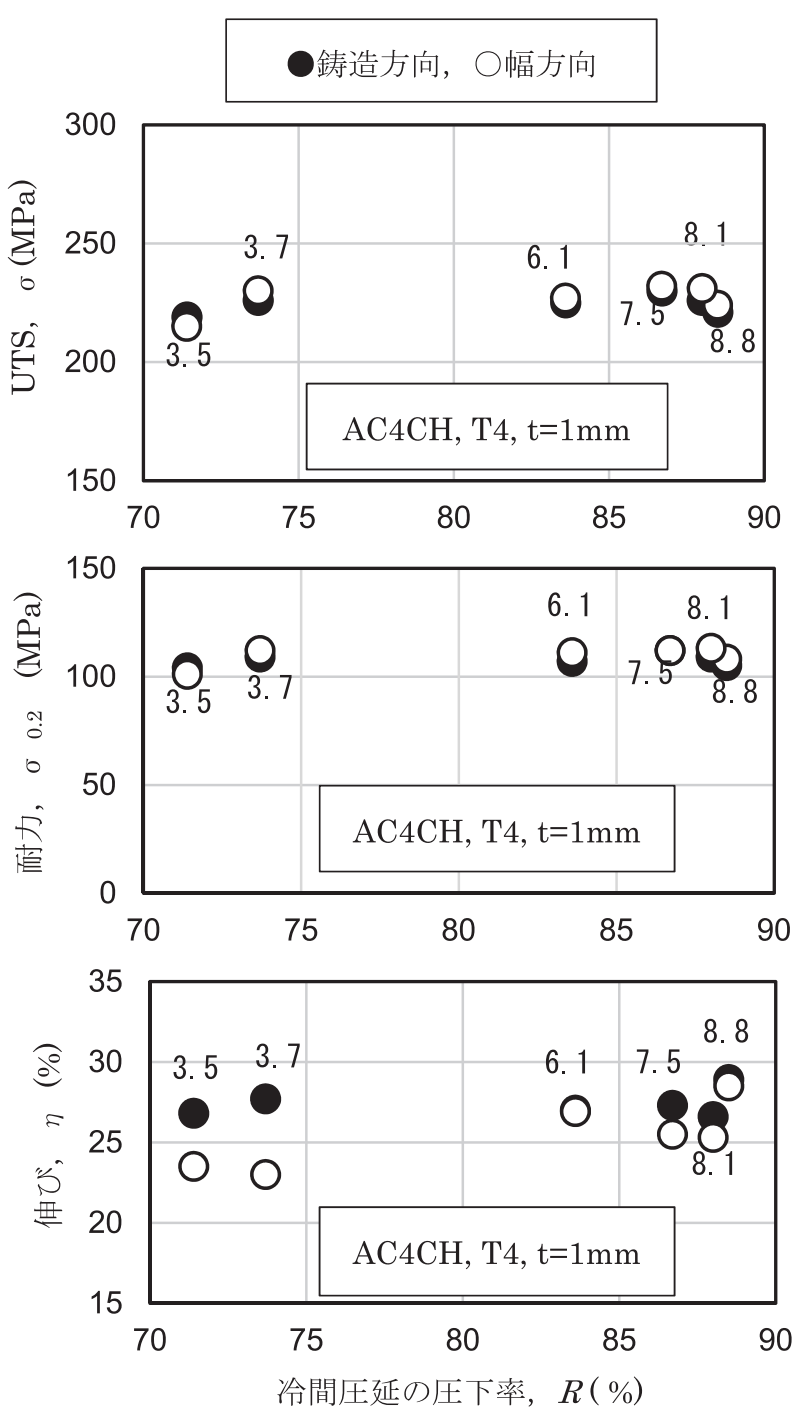

図13 $\mathrm{AC4CH}$ の鋳造方向と板幅方向の引張試験の結果 に対する冷間圧延の圧下率の影響

異なる厚さの鋳造板を $1 \mathrm{~mm}$ の厚さに冷間圧延した

で鋳造した板には中心線偏析は発生しないが, 自由凝固面は 平坦ではなく凹凸がある。また，メルトドラッグ法は単ロー ルキャスターのため, 双ロールキャスターのように鋳造板は ロールに押し付けられない。このため冷却が不十分であり， 5182 やAC7A では鋳造板は破断してしまい連続的に板を鋳造 することができなかった。自由凝固面の平坦化, および板 （凝固層）をロールに押し付けて冷却させることを目的とし てスクレイパーを考案した ${ }^{14)}$ 。スクレイパーを装着した単 
燒きなまし

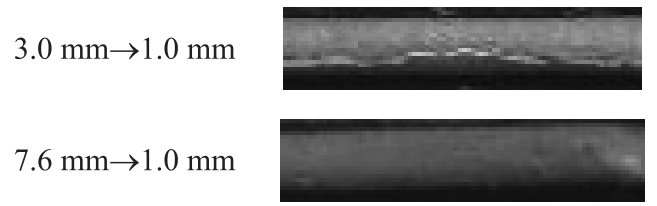

$\mathrm{T} 4$

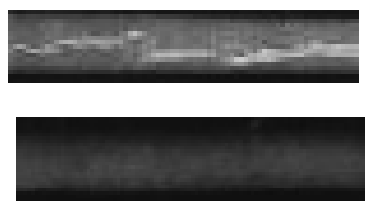

図 14180 度曲げ行った時の外面の割れに対する鋳造板の厚さの影響

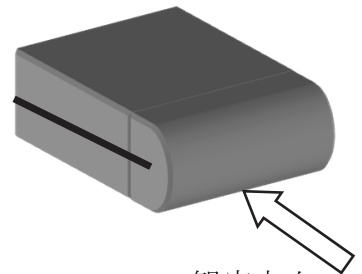

観察方向 鋳造板を $1.0 \mathrm{~mm}$ まで冷間圧延し，焼きなまし，または T4後に $180^{\circ}$ 曲げ
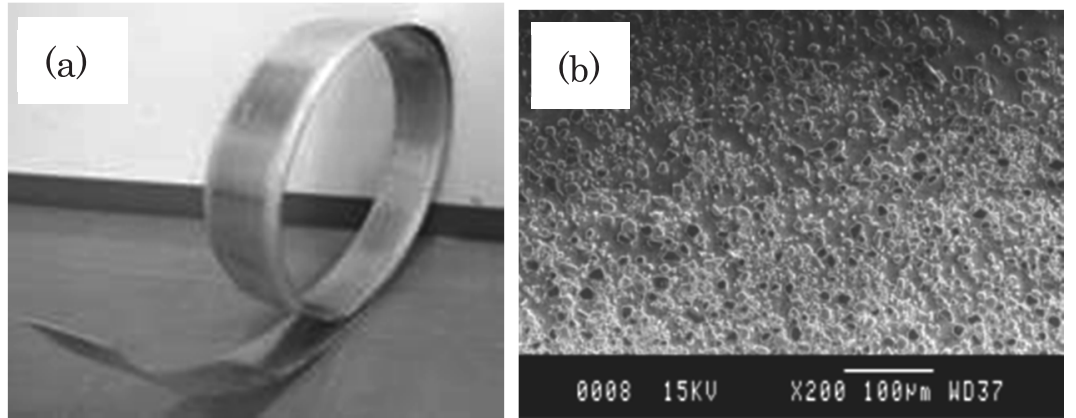

図 $15 \mathrm{Al}-\mathrm{SiC}_{\mathrm{p}}$ 鋳造板のコイルと鋳造板の断面 (a) $\mathrm{Al}-20 \mathrm{vol} \% \mathrm{SiC}_{\mathrm{p}}$ 鋳造板のコイル，コイル径 $460 \mathrm{~mm}$, (b) $\mathrm{Al}-30 \mathrm{vol} \% \mathrm{SiC}_{\mathrm{p}}$ 鋳造板の断面，粒は $\mathrm{SiC}$ 粒子

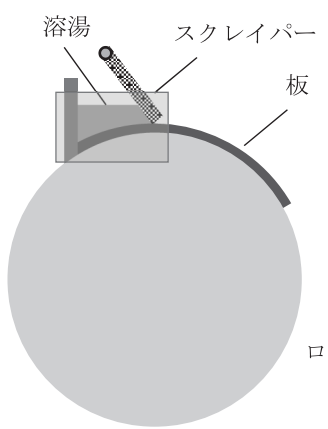

(a) 全体

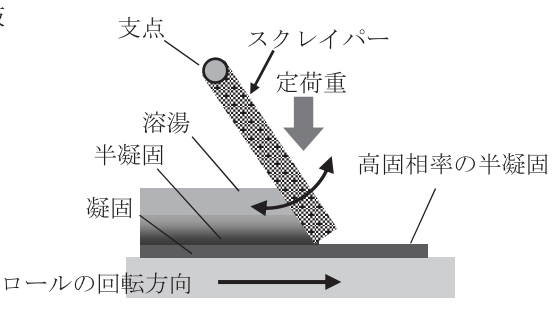

(b) スクレイパー周辺

図16 スクレイパーを装着した単ロールキャスター

ロールキャスターの模式図を図16に示す。単ロールキャス ターであるが30 $60 \mathrm{~m} / \mathrm{min}$ のロール周速で板を鋳造できる。 スクレイパーは回転支持の板であり, スクレイパー荷重（ス クレイパーが板をロールに押し付ける荷重）は $0.2 \mathrm{~N} / \mathrm{mm}$ 程度 と小さい。スクレイパーで成形直後の板の表面は半凝固状態 であった。スクレイパー荷重が小さいため， $\mathrm{Al}-\mathrm{Mg}$ 合金やマ グネシウム合金においてもロール接触面には割れが発生しに くい。0.2 N/mm程度のスクレイパー荷重でも鋳造板の冷却は 向上し，5182や AC7A，さらに $\mathrm{Mg}$ 量が10\%の AC7Bの板を連 続的に鋳造することができた。しかし，AC7Aに $2 \%$ の Siを加

えた合金は，延性に対する冷却速度の影響が大きく，スクレ イパーを装着した単ロールキャスターではスクレイパー成形 面の冷却が不十分で $\mathrm{Mg}_{2} \mathrm{Si}$ が粗大化し，良好な延性を得られ なかった。また, 鋳造板の両端にばりが発生しないこともス クレイパーを装着した単ロールキャスターの特長である。 5182 板の厚さ分布を図 17 に, 板の断面を図 18 に示す。縦型 高速双ロールキャスターで鋳造した板に深絞りを行うと図 19(a)に示すように縞や割れが発生する場合がある。しかし, スクレイパーを装着した単ロール法で鋳造した板では図 19 （b），(c）に示すように縞や割れは発生しなかった。鋳造板の ロール接触面とスクレイパー成形面の差異は, 冷間圧延後 は, 目視では確認できなかった。深絞り試験のカップの肩部 の荒れは, 絞り比が 1.8 程度までは差異はないが 2.0 になると 焼きなまし条件によってはスクレイパー成形面の方が粗くな る場合があった。

\section{6. クラッド板}

縦型高速双ロールキャスターの複数使用, および縦型高速 双ロールキャスター，または異径双ロールキャスターにスク レイパーを装着することでクラッド板の鋳造が可能であ る ${ }^{15)-17)}$ 。代表的なクラッド板鋳造用双ロールキャスターを 図20に示す。図20(a) では，3層のクラッド材を鋳造するこ

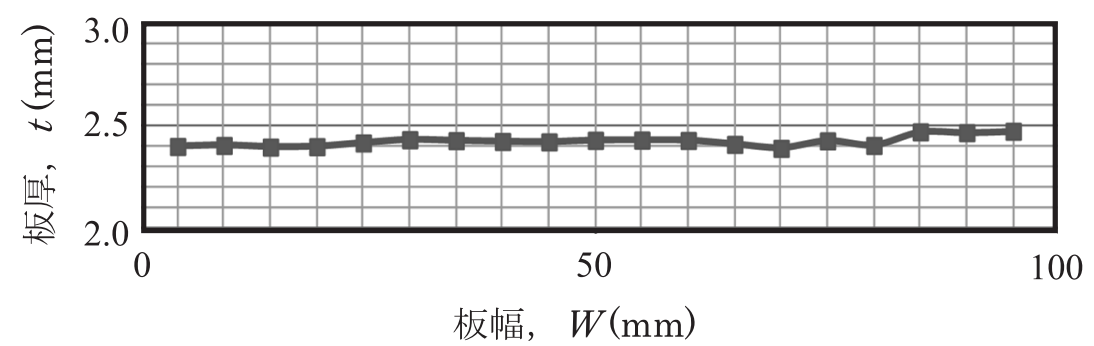

図17 スクレイパーを装着した単ロールキャスターを使用してロール周速 $40 \mathrm{~m} / \mathrm{min}$ で鋳造した 5182 板の厚さ分布 


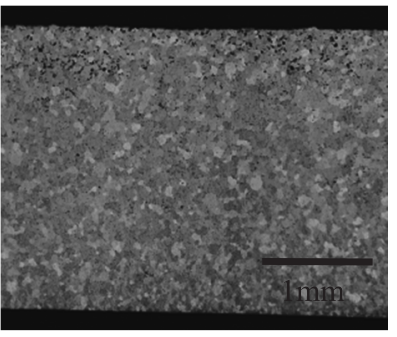

(a)

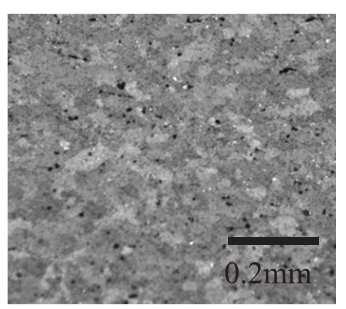

(b)
図18 スクレイパーを装着した単ロールキャスターで鋳 造した 5182 板の断面組織（a）鋳造板，（b) $1 \mathrm{~mm}$

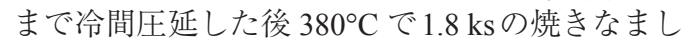

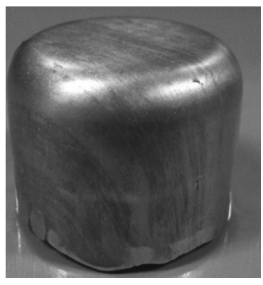

(a)

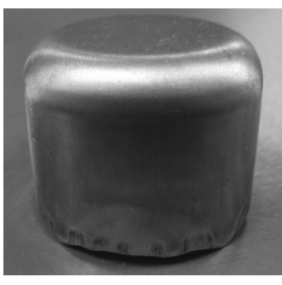

(b)

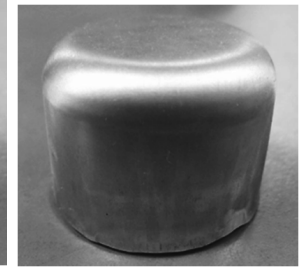

(c)
図 195182 板の深絞り試験の結果 鋳造板を $1 \mathrm{~mm}$ まで 冷間圧延，焼きなましを行った後に深絞り，パ ンチ径 $32 \mathrm{~mm}$ （a）縦型双ロールキャスターで 鋳造, (b) スクレイパーを装着した単ロールキャ スターで鋳造，スクレイパー成形面が外側，（c） スクレイパーを装着した単ロールキャスターで 鋳造，ロール接触面が外側

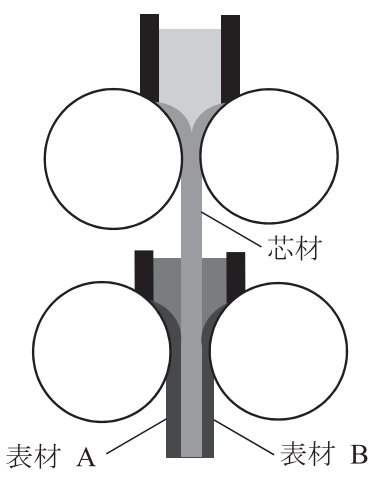

(a)

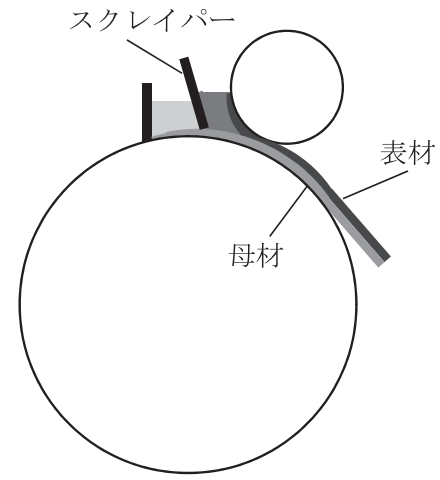

(b)
図20 代表的なクラッド板鋳造用双ロールキャスター (a) 縦型タンデム双ロールキャスター,（b）ス クレイパーを装着した異径双ロールキャスター

とができるが，縦型高速双ロールキャスターを3台使用し，5 層のクラッド板を鋳造することも可能であった。また，表材 $\mathrm{A}$ と表材 $\mathrm{B}$ は異なるアルミニウム合金を使用することもでき る。芯材の表層が半凝固状態になるまで加熱されることに よって芯材と表材は接合すると考えられる。表材の凝固潜熱 が小さい合金の場合は, 図20(a)では接合しない場合がある。 図 20 (a) では, 表材の液相線温度と注湯温度が芯材の固相線 温度より低い場合でも接合する場合もあるが, 表材の液相線 温度が芯材の固相線温度より高く, 注湯温度が芯材の液相線 温度より高い場合でも接合しない場合がある。図20(a) の方 法では, 接合の可否に対する表材の凝固潜熱の影響は大き い。これに対し図20（b）のスクレイパーを使用する場合は, スクレイパー近傍の母材の表面は, 高固相率の半凝固状態で

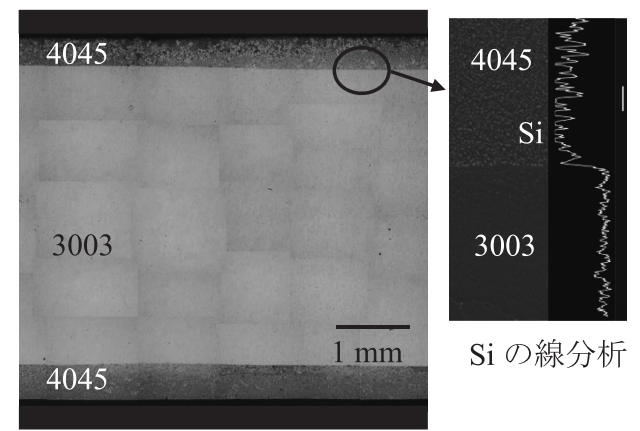

(a)

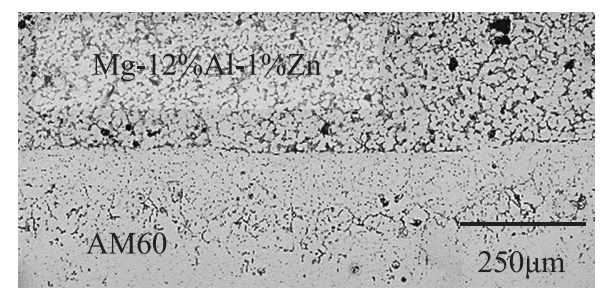

(b)

図21 クラッド板の断面（a）縦型タンデム双ロール キャスターで鋳造したアルミニウム合金の3層ク ラッド板, （b）スクレイパーを装着した異径双 ロールキャスターで鋳造したマグネシウム合金 の 2 層クラッド板

あるため，接合に対して表材の凝固潜熱の影響を受けにく い。スクレイパーを使用する場合は酸化雲囲気中で鋳造を 行っても母材の表面が酸化䨌囲気に触れることは無い。例え ばマグネシウム合金のように酸化しやすい合金であってもク ラッド板を鋳造することができる。アルミニウム合金および マグネシウム合金のクラッド板の断面を図 21 に示す。図 21 （a）は図 20(a) の方法により鋳造した芯材が3003, 表材が 4045 の 3 層クラッド板の断面と Si の線分析の結果である。芯 材と表材の接合界面は明瞭であり, 表材の 4045 の Siは芯材の 3003 の内部まで拡散していないことがわかる。図21(b) は図 20 (b) の方法により鋳造した母材がAM60, 表材がMg-12\%Al$1 \% \mathrm{Zn}$ の 2 層クラッド板である。酸化しやすいマグネシウム合 金であっても大気中でクラッド板の鋳造が可能であった。 Mg-12\%Al-1\%Znのように $\mathrm{Al}$ 量が多く硬いマグネシウム合金 であっても，双ロールキャスターを使用すると 1 工程で容易 にクラッド板を鋳造することができた ${ }^{17) 。 ~}$

母材が 1070 , 表材が $\mathrm{Al}-40 \% \mathrm{Sn}-1 \% \mathrm{Cu}$ の 2 層クラッド板を, スクレイパーを装着した異径双ロールキャスターで鋳造して いる様子を図 22 に示す。表材の液相線温度は $610^{\circ} \mathrm{C}$, 固相線 温度は $228^{\circ} \mathrm{C}$ と大変低い。表材の液相線温度は母材の固相線 温度よりも低い。表材はロール間隙でクラッド板に成形され るが未凝固であり, 搬送後にクラッド板の温度が低下し凝固 は完了すると考えられる。鋳造材と冷間圧延後のクラッド板 の引張せん断試験後の試験片を図23に示す。接合界面では剥 離せず強固に接合していることがわかる。また, 冷間圧延後 のクラッド板の接合界面近傍における $\mathrm{Sn}$ の線分析の結果を 図 24 に示す。Al-40\% $\mathrm{Sn}-1 \% \mathrm{Cu}$ の温度が固相線まで低下する までに10分程度かかったが, Snが1070に拡散しなかった。 


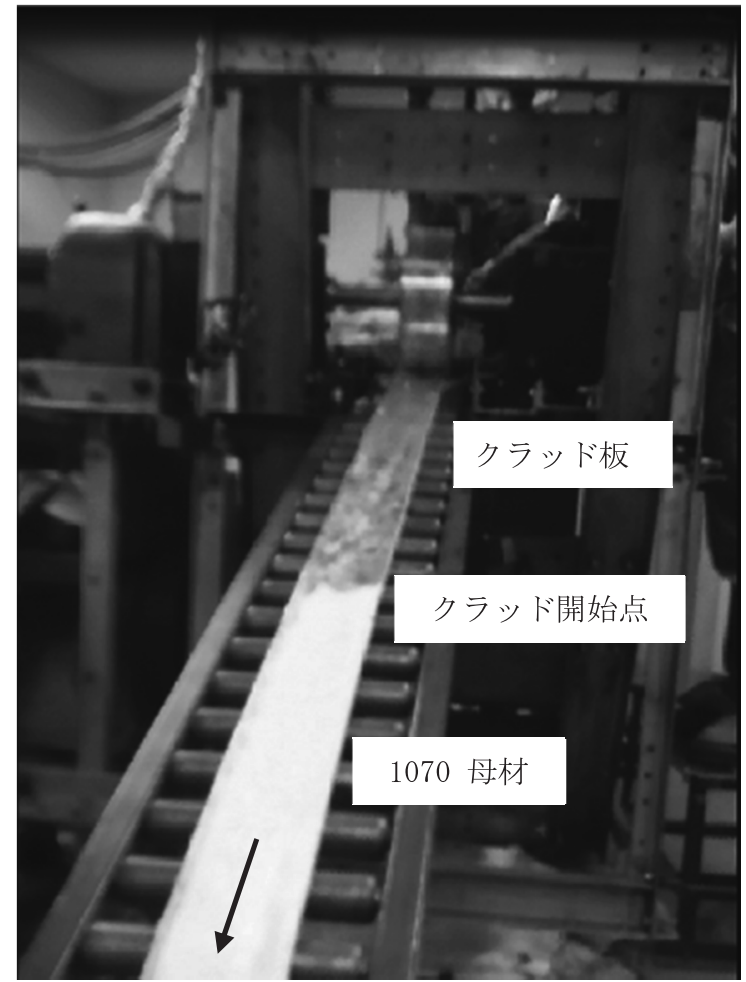

図22 母材が 1070 ，表材が $\mathrm{Al}-40 \% \mathrm{Sn}-1 \% \mathrm{Cu}$ のクラッド 板の鋳造

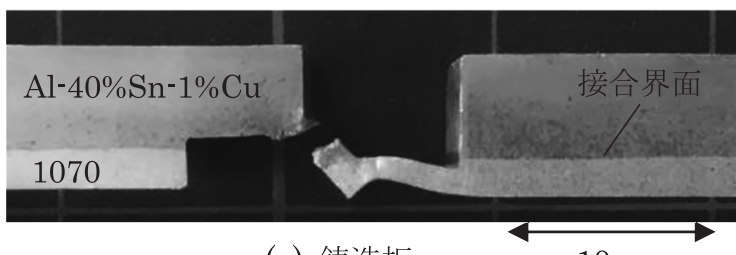

(a) 鋳造板

$10 \mathrm{~mm}$

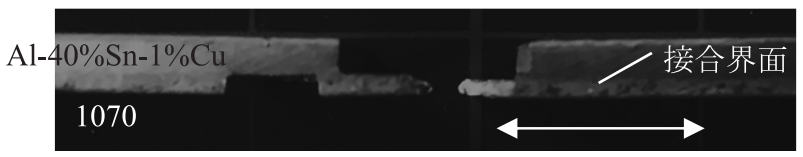

$10 \mathrm{~mm}$

(b) 厚さ $2 \mathrm{~mm}$ の冷間圧延板

図23引張せん断試験後の試験片

\section{7. 複 合 材}

メルトドラッグ法に下方メルトドラッグ法を付加した双 ロールキャスターを使用してステンレス製の針金や金網を板 の中に挿入した複合材板を鋳造する方法を検討した ${ }^{18), 19) 。 ~}$ プロセスの概要と金網を挿入した鋳造板の断面を図 25 に示 す。針金や金網の搬送・挿入装置を必要とせず，鋳造板が針 金や金網を引き込み，容易に長䋊維の複合材板を作製でき た。針金または，金網を挿入した引張試験の結果，挿入した 金網の針金が鋳造方向に対して斜めの場合, 図26に示すよう に伸びが向上した。金網の挿入により局部収縮が低減された ためであると考えられる。

\section{8. インライン圧延}

高速双ロールキャスターで鋳造したAC7A板のインライン 圧延を試みた ${ }^{20)}$ 。 $\mathrm{AC} 7 \mathrm{~A}$ 板の内部の温度は, 熱電対を挿入し

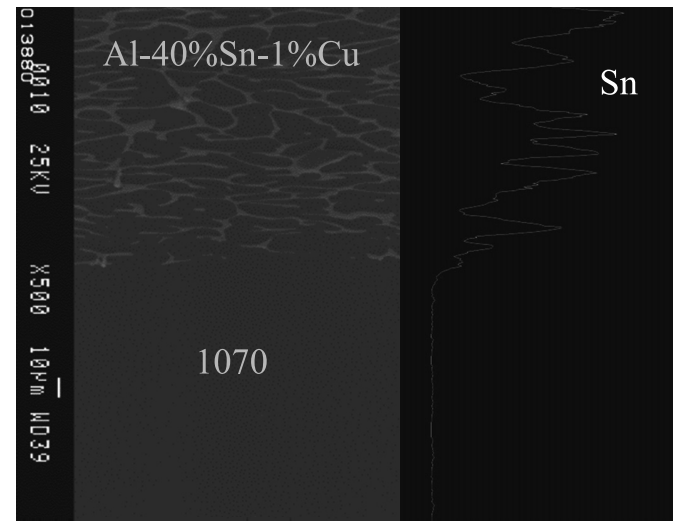

図24厚さ $2 \mathrm{~mm}$ まで冷間圧延した 1070 と Al-40\%Sn$1 \% \mathrm{Cu}$ のクラッド板の接合界面近傍の $\mathrm{Sn}$ の線分析
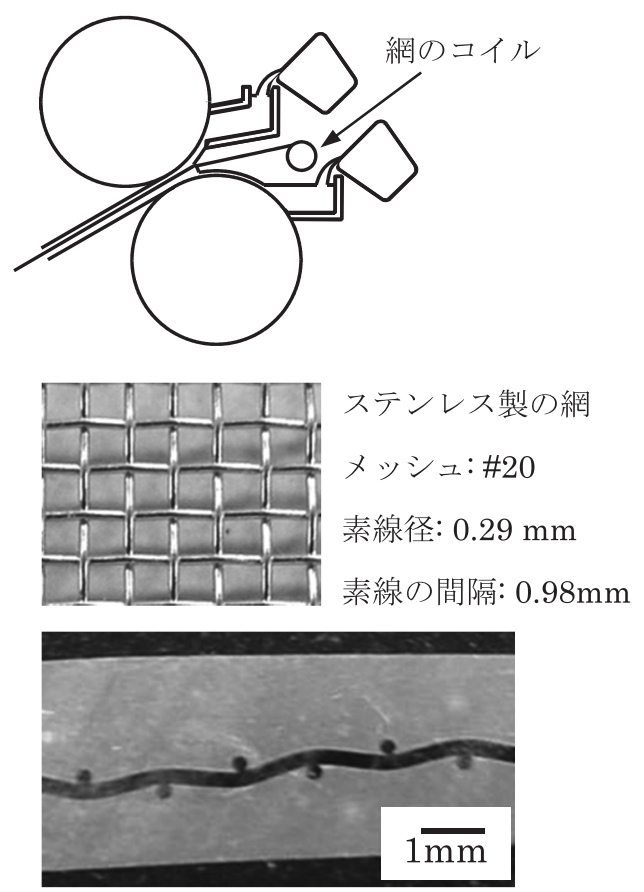

図25金網を挿入した板を鋳造するための双ロール キャスターと金網を挿入した板の断面

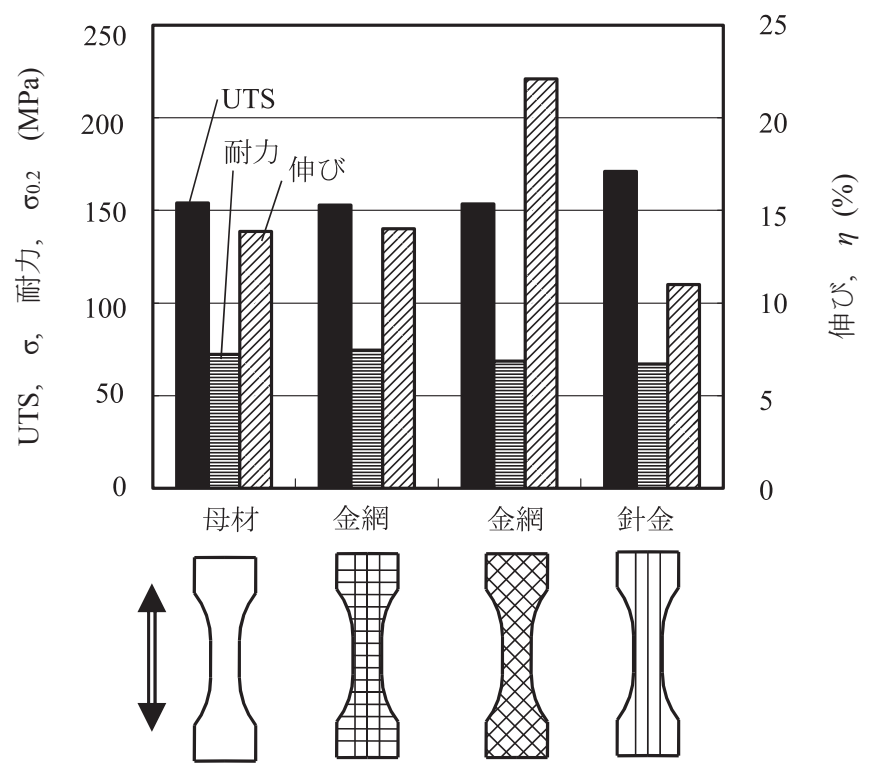

図 26 鋳造板，金網を挿入した鋳造板，針金を挿入し た鋳造板の引張試験の結果 


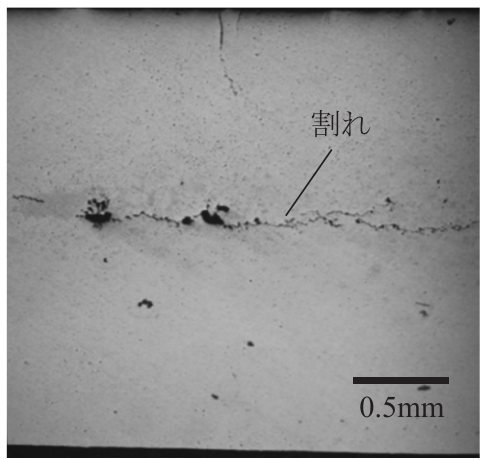

(a)

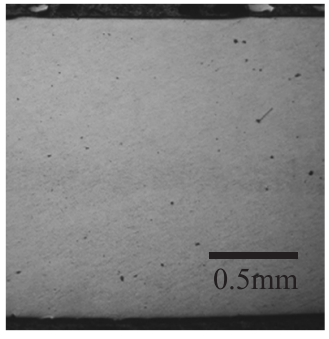

(b)

図27縦型高速双ロールキャスターで鋳造した 6022 板 とインライン熱間圧延をした 6022 板の断面 (a) ロールキャスト板, （b）インライン熱間圧延板

た温度測定より $400^{\circ} \mathrm{C}$ 以上であると推測している。板の内部 の温度に関しては現在もデータを蓄積中である。AC7Aであ れば熱間または半凝固状態でインライン圧延が可能である。 インライン圧延板の深絞りでは, 図19(a) に示したような縞 や割れが低減したのでインライン圧延は中心線偏析や表面割 れの改善に効果があると考えられる。高速双ロールキャス ターで鋳造した6022板には厚さ方向の中央部に図27(a)に示 すように割れが発生する場合がある。冷間圧延では割れは圧 着できなかったがインライン熱間圧延では図 $27(\mathrm{~b})$ に示すよ うに割れを圧着することができた。実操業では，高価な熱間 圧延機の生産能力を活かすためには，双ロールキャスターの 生産性を高くする，つまりロール周速を高速にする必要があ る。高速ロールキャスターは従来の双ロールキャスターより インライン圧延に適していると考えられる。

\section{9. 結言}

高冷却能の高速ロールキャスターは, $\mathrm{DC}$ 鋳造の代替プロ セスではなく，その特徵を生かした使用方法を検討すべきで あると考えられる。例えば高冷却速度を活かし，鋳造用合金 をベースにした合金によるユニアロイ化やリサイクル材の無 害化である。インライン压延は，ロールキャスター単体では

不可能な欠陥や材質の改善に有用であると考えられる。

また，クラッド材鋳造用の双ロールキャスターは，クラッ ド板の作製が不可能とされていた材料のクラッド板を可能に する。従来から使用されている素材がクラッド板という形で 新たな価值を有することも期待される。

\section{参 考 文 献}

1) 羽賀俊雄, 石原勝之, 片山 剛, 西山丈司：軽金属, 48 (1998), $613 \sim 617$.

2) T.Haga: J. Mater. Process. Technol., 111 (2001), 64-68.

3) 松下敏郎, 中山勝巳, 深瀬久彦, 長田史郎：IHI技法, 48 (2008), $77-84$

4) K.Suzuki, S.Kumai, Y.Saito, A.Sato and T.Haga: Mater. Trans., 45 (2004), 403-406.

5) T.Haga and K.Takahashi: Mater. Sci. Forum, 449-452 (2004), 145148.

6) T.Haga, M.Ikawa, H.Watari, K.Suzuki and S.Kumai: J. Mater. Process. Technol., 172 (2006), 271-276.

7) T.Haga, K.Hirooka, H.Watari and S.Kumai: Archives Mater. Sci. Eng. 30 (2008), 117-120.

8) T.Haga, AIP Conference Proceedings, 1769 (2016), 030003.

9) T.Haga, T.Yamashiki, H.Watari and S.Niahida: Key Eng.Mater., 831 (2020), 40-45

10) 羽賀俊雄：軽金属学会第138回春期大会講演概要, (2020), 253254.

11) 羽賀俊雄, 坂田裕崇, 惣田裕司：軽金属学会第 137 回秋期講演 大会概要, (2019), 229-230.

12) 日下田雅男, 須田直人, 松崎邦男, 羽賀俊雄：鋳造工学, 88 (2016), 730-734

13) H.Watari, Y.Nishio, M.Suzuki, T.Haga, K.Davey and N.Koga: , Mater. Sci. Forum, 654-656 (2010), 1440-1443.

14) T.Haga, K.Akitsu, T.Yamabayashi, S.Kumai, H.Watari, Key Eng. Mater., 443 (2010), 122-127.

15) T.Haga, R.Nakamura, S.Kumai and H.Watari: J. Achiev. Mater. Manuf. Eng., 62 (2013), 36-44.

16) T.Haga, H.Tsuge, T.Ishihara, S.Kumai and H.Watari: Key Eng. Mater., 611-612 (2014) 623-628.

17) T.Haga, K.Okamura, S.Nishida, H.Watari and K.Matsuzaki: Mater. Sci. Forum, 879 (2017), 671-676.

18) T.Haga, K.Takahashi, S.Kumai and H.Watari: Adv. Mat. Res. 264-265 (2011), 1899-1904.

19) T.Haga, K.Takahashi, S.Kumai and H.Watari: Adv. Mat. Res. 337 (2011), 556-559.

20) T.Haga, S.Hanada, S.Kumai and H.Watari: Mater. Sci. Forum, 654-656 (2010), 795-798. 